Gavilea. Para esto, evaluamos la señal filogenética de diferentes rasgos de estas especies, analizando cuáles caracteres son más plásticos y cuáles se han mantenido más estables a lo largo de la filogenia de este taxón. Además, quisimos evaluar si dentro de los rasgos florales había algunos que estuvieran evolucionando en forma correlacionada. Evaluamos la señal filogenética y todos presentaron un índice $\mathrm{K}$ de Blomberg menor a 1 , no significativo $(\mathrm{P}>0,05)$ y un valor de lambda cercano a cero, sugierendo que los rasgos florales son evolutivamente plásticos. Sin embargo, al evaluar la correlación entre rasgos florales a través de contrastes independientes, se observó una correlación significativa entre varios de éstos, como el largo del sépalo dorsal con el largo del sépalo lateral, y el largo de las caudículas con el largo de los sépalos laterales, entre otros. Podemos concluir que los rasgos florales son evolutivamente plásticos en la filogenia de este género y que a su vez, algunos de éstos presentan una evolución correlacionada.

\title{
Atlas of orchids of the state of Santa Catarina
}

\author{
Marcelo Vieira Nascimento \\ Av. Dep. Diomicio Freitas 3160 - Casa 12, Bairro Carianos, Florianópolis/Santa Catarina, Brasil \\ mar@floripa.com.br
}

The state of Santa Catarina has a land area of $95,346,181 \mathrm{~km}^{2}$, totaling $1.19 \%$ of the total area of Brazil. The vegetation of the state consists of the following biomes: tropical Atlantic Forest coast, consisting of mangroves, dunes, beaches, and sandbanks; subtropical forest of Uruguay, with small vegetation; Araucaria forest, which is primarily composed of pine, cinnamon, cedar, yerba mate, and tree fern. In the plateau region we find the fields, the coldest region of the state. Despite representing only $1.19 \%$ of the total area of Brazil, the state is rich in the quantity and quality of orchids. Without doubt the most famous is Laelia purpurata, the official flower of the state of Santa Catarina and its capital Florianópolis. The Orchid Atlas of Santa Catarina is a unique initiative to disclose clearly and objectively the occurrence of the Orchidaceae there. The methodology for the Atlas is basically to 1) research the 14 herbaria in the state of

Santa Catarina, as well as São Paulo and Rio de Janeiro, trying to identify the vouchers from Santa Catarina; 2) review existing literature for Orchidaceae of Santa Catarina; 3) perform field work in all biomes of Santa Catarina over two years, trying to identify the species found and seeking confirmation of what has been deposited in the herbaria as well as other collections that perhaps have not yet been identified or registered for the state; 4) use GPS and GIS to prepare thematic maps of biomes and the location of the species found; and 5) identify, map, and photograph the biomes, listing for each one the genera and species occurring there as well as botanical descriptions and photos of the habitat, the plant as a whole, and the individual flower. So far we have found and identified 119 works, 465 orchid species, two subspecies, four varieties, and 16 endemic species of Santa Catarina. Monitoring of project results can be viewed at www.orquidarionsdodesterro.com.br.

\section{Orchidacae of Campeche Island, Florianópolis, Santa Catarina}

\author{
Marcelo Vieira Nascimento \\ Av. Dep. Diomicio Freitas 3160 - Casa 12, Bairro Carianos, Florianópolis/Santa Catarina, Brasil \\ mar@floripa.com.br
}

Campeche Island was declared a National Landscape and Archaeological Site through the Ministerial Decree No. 270, July 2000. It has an area of $4.0 \mathrm{~km}^{2}$. The existing plant diversity in the Island of
Campeche is provided by the different habitats found there: 1) sandy coastline, characterized by having a poor soil consisting mainly of fragments of quartz $(0.2$ to $10.0 \mathrm{~mm}$ in size), high permeability to water, and 
high salt content. The plants found there are psamófitohalophytes, small in size with abundant roots and long, leathery leaves; 2) rocky coastline, characterized by the presence of Dyckia encholirioides (Bromeliaceae); 3) forest, with many rocky outcrops and sparse herbaceous layers because the penetration of light in most places is low. This study was conducted between 2010 and 2011 , in conjunction with the graduate program at the University of Lavras-MG - Botany Ornamental Plants. Herbarium specimens deposited in the Herbaria Barbosa Rodrigues (RBR) and the Federal University of Santa Catarina (FLOR) were consulted and studied. The field work on the island of Campeche occurred over the years 2010 and 2011, totaling 49 trips lasting three days each. By the end of this work, 25 genera and 34 species of orchids and a natural hybrid were catalogued, described, and photographed. The genera and species found were: Acianthera pubescens, A. serpentula, A. saundersiana, A. sonderana; Aspidogyne bidentifera; Brassavola tuberculata; Campylocentrum aromaticum; Catasetum cernuum; Cattleya leopoldii; Cyrtopodium flavum; Cleistes macrantha; Encyclia odoratissima; Epidendrum fulgens; Gomesa crispa; Maxillaria picta; Miltonia flavescens; Notylia longispicata; Octomeria grandiflora, O. montana, O. diaphana); Oeceoclades maculata; Oncidium pumilum, O, flexuosum, O. ciliatum, O. barbatum; Ornithocephalus myrticola; Polystachya estrellensis; Prescottia densiflora; Rodriguezia decora; and Stanhopea graveolens.

\title{
Cattleya labiata Lindl. and its varieties - a reflection
}

\author{
Marcelo Vieira Nascimento \\ Av. Dep. Diomicio Freitas 3160 - Casa 12, Bairro Carianos, Florianópolis/Santa Catarina, Brasil \\ mar@floripa.com.br
}

Cattleya labiata was discovered in 1818 by William Swainson during his scientific expedition to Brazil. It was described by English botanist John Lindley in 1821. The specific plant came from northeastern Brazil, far from the coast and 500 to $1000 \mathrm{~m}$ above sea level where the temperature oscillates between 18 and 22 C. The varieties of Cattleya labiata have always been subjects of much controversy among Brazilian hobbyists. A variety in the orchid sense should be based on the existence of more than one factor, including flower shape, color, design, texture, size, and substance. Over the past 20 years several authors and Brazilian organizations, such as L. C. Menezes, João Paulo de Souza Fontes, Federation of Orquidofilia Gaucha, and Federation of Santa Catarina Orquidófilia, have created their own lists of varieties. According to these works and combining information from charts and table, 37 varieties of Cattleya labiata have been described based on the color and shape of the flower and 12 varieties based on the design of the lip.

\section{Novelties in Orchidaceae for the Colombian flora}

\section{Oscar Alejandro Pérez-Escobar ${ }^{1 *}$, Pedro Ortiz Valdivieso ${ }^{2 \dagger}$, Edicson Parra- SÁncheZ ${ }^{3}$, Cristian Rincón-Useche ${ }^{4}$ \& Lizeth Katherine RodrígueZ ${ }^{4}$}

${ }^{1}$ Faculty of Biology, Ludwig Maximilians Universität, Botanischer Garten München, Menzinger Straßer 65, 80638

München, Germany; ${ }^{2}$ Pontificia Universidad Javeriana, Bogotá, Colombia; ${ }^{3}$ Faculty of Biology, Universidad

Nacional de Colombia; ${ }^{4}$ Faculty of Agricultural Sciences, Universidad Nacional de Colombia-Sede Palmira, Colombia; *correspondence: oapereze@yahoo.com

During floristic inventories conducted in remnant cloud forests and páramos from the western and eastern Cordilleras of the Andes, several new species and chorological novelties have been reported as the result of intensive field and herbarium work since 2009. Material from each species found was collected and documented with pictures and field notes; several dried specimens from the most representative herbaria 